\title{
The Latest Italian Labour Market Reforms in the Perspective of Decent Work Basic-Relations-Fairness Proposal
}

\author{
Martina Lavagnini University of Roma Tre, Italy \\ Antonella Mennella, University of Roma Tre, Italy
}

\begin{abstract}
This work is a contribution to the debate on 'decent work', here developed as an instrument to measure an aspect of human development. The concept, conceived by the International Labour Organisation (ILO) in 1999, is here interpreted in relation to Sen's (1999) capability approach. The main idea is that decent work 'can be a liberator' (Sen, 1999: 116). Elements identified in the basicrelations-fairness proposal are grouped into three profiles, which are ordered into two levels. Obstacles to decent work or 'working defects' are understood as the distance from the actual to the desired labour condition, and improvements of the quality of labour are interpreted as approaching the desired situation. The proposal is firstly presented theoretically, then used to interpret labour market reforms in Italy from the 'Treu law' in 1997 to 'Fornero reform' in 2012.
\end{abstract}

\section{KEYWORDS}

Decent work, capability approach, Italian labour market, labour quality.

\section{Introduction}

In recent years, there has been an intense debate on how to measure decent work around the world's regions and how to compare country performances over the years. This debate is still open and lively, and the aim of this work is to take part in it by proposing a multidimensional approach to the decent work measure. It proposes a connection between development and labour market analysis which could enrich the study of labour markets by focusing on the worker. The concept of decent work was conceived by the ILO in 1999 and defined as: 'opportunities for women and men to obtain decent and productive work, in conditions of freedom, equity, security and human dignity' (ILO, 1999: 3).

In this study we link decent work to Sen's (1999) capability approach and offer a methodology to calculate it. We propose that decent work is articulated through three profiles: basic, relations and fairness. These will be prioritised into two levels: basic is the fundamental one and concerns elements of the daily working conditions, relations and fairness are complementary and group indicators linked to the social aspect of working.

The approach will be tested by analysing the case of Italy and observing the impact on decent work of labour market laws and reforms over the last 15 years. The empirical analysis uses data from different sources, including the ISTAT (National Institute of Statistics) labour force survey, statistics 
on accidents and diseases from INAIL (National Institute for Assurance on Accidents at Work), data from the INPS (National Institute of Social Protection) observatories on workers, EUROSTAT and OECD databases.

In the following section the decent work basic-relations-fairness proposal is defined and its methodology explained. The third section is a short description of reforms concerning the Italian labour market. In the fourth section the proposed approach is used to evaluate decent work in Italy. In the last section conclusions are drawn.

\section{The Decent Work Basic-Relations-Fairness Proposal}

'Paid work contributes to quality of life both positively and negatively. Paid work provides income as well as identity and social interactions, but it may also be a source of negative experiences and risks' (Stiglitz, Sen and Fitoussi, 2009: 172).

In 2009 a large ILO project - Monitoring and Assessing Progress on Decent Work (MAP) investigated decent work indicators across countries over a period of four years. Thanks to this project it has been possible to collect data of different nature and offer them as a tool for economic policy analysis (ILO, 2013).

Furthermore the decent work debate has proposed whole dashboards of indicators that accommodate the social and economic conditions of the entire economy (e.g. Anker et al., 2002), but it has also proposed proxy numbers which concentrate instead on a few selected indicators of working conditions (e.g. the index of labour morale by Godfrey, 2003). Dissimilarities between approaches originate from the theoretical assumption taken about the identity of the depositary of decent work: either the individual or the worker or the employer.

The first and official definition of decent work refers to 'women and men' and so studies have often been extended to the entire economy so that any kind of relationship between a person and work was part of the decent work analysis. But different interpretations are possible, focusing on the whole population that has or had an active relationship with the labour market (employed, unemployed, retired, etc.) (Ghai, 2002).

The analysis can also focus on working conditions and the right of the worker to aspire to and experience decent work, and so does the basic-relations-fairness proposal. The peculiarities of the economy and characteristics of its labour market are obviously important as these are the fields where work is created and takes place, but the aim of this interpretation of decent work is to investigate the individual and relational conditions of the person while working. Even if work is such an important possibility for people and has social and personal effects on non-working moments as well, it is still possible to analyse worker's and people's conditions separately: 'In the broad concept of decent work the main focus is on work per se' (Saith, 2004: V).

Democratic states recognise the great and positive intrinsic value to labour in itself. The first article of the Italian Constitution states that 'Italy is a democratic Republic, based on work'. It is also commonly perceived that through work a person can find a way to self-expression, or at least to attain social respectability. Studies show that when not working individuals suffer psychologically as well as socially (besides the obvious drop in income)' (Krauser, 2011: 1). So, in line with the capability approach, ${ }^{1}$ the proposed interpretation of decent work aims mainly to detect 'labour unfreedoms', in the belief that, if not under given constraints, labour, in its multifarious possibilities, can enlarge the range of human capabilities.

As it is neither possible nor desirable to list the benefits that a person can achieve through labour, the identification and the removal of labour unfreedoms is sufficient to liberate the power of labour as a mean for people to 'lead the kind of lives they have reason to value' (Sen, 1999: 10). 
Listing the positive contributions of work is impossible because the range of human creativity applied to changing market and socio-cultural circumstances can generate an infinite choice of functionings. So as long as the persons involved in the labour relation are using their 'reasoned agency' (Sen, 1999: xii) to behave among fully available capabilities (whether making choices of action or of non-action), the resultant functionings cannot be unfree. The destination of development - in terms of the capability approach as applied here - therefore resides inside human beings and their personal mutual relations. It is more an attitude to realising development through the destruction of constraints than the accrual of specific conditions. ${ }^{2}$

The framework here developed is coherent with the capability approach, but it is an innovative contribution for the development analysis in a decent work perspective.

The indicator proposed is composed of three parts, placed into two levels (as described in Figure 1).

\section{$\underline{\text { Figure } 1}$}

\section{The $\underline{D W}$ basic-relations - fairness proposal :}

\begin{tabular}{|c|c|c|c|c|}
\hline \multicolumn{4}{|c|}{ B A S I C } & \\
\hline working hours & physical safety & legality of jobs & \multicolumn{2}{|c|}{ unemployment rate } \\
\hline defect & defect & defect & pressure & \\
\hline \multicolumn{2}{|c|}{ RELAT I O N S } & \multicolumn{3}{|c|}{ F A I R N E S S } \\
\hline \multicolumn{2}{|c|}{$\begin{array}{l}\text { monetary sufficiency/ } \\
\text { monetary enrichment }\end{array}$} & \multicolumn{2}{|c|}{$\begin{array}{c}\text { irrelevance of private } \\
\text { characteristics }\end{array}$} & defect \\
\hline \multicolumn{2}{|c|}{ educational enrichment } & \multicolumn{2}{|c|}{\begin{tabular}{|l} 
hanging work \\
\end{tabular}} & \\
\hline \multicolumn{2}{|c|}{ freedom to voice } & & & \\
\hline
\end{tabular}

\subsection{Fundamental Level: Basic Profile}

The basic profile regroups fundamental indicators, which are characterised as those more intimately linked to the daily working conditions. For these indicators it is possible to point out a chosen desired value, and the gap, whether positive or negative, between the actual and the desired value is recorded as a decent work basic defect. The approach draws on Bescond, Chataignieer and Mehran (2003), where the aim of the methodology is to identify the percentage (in that case the average percentage) of workers who live a decent work deficit. Defects are labour unfreedoms, and the chosen desired value (or range) is where freedom lays.

The first basic physical and psychological indicator is working hours. The amount of personal time spent on working activities is the most important element of decent work. Time is a nonrenewable personal resource, and the opportunity cost of working an hour more after regular 
working time - no matter how personally satisfying the job is - is unlikely to be rewarded by the overtime hourly wage.

In every economy a range of formally accepted workweek lengths and contract types can be identified that show how people can share and organise their work through time, both as employed and self-employed. Once a range is detected, that range is the target for this basic aspect. For Italy the right amount of working hours is identified as being between 20 and 40 hours per week, corresponding respectively to a part-time and a full-time employee contract. Working more and working less are equally undesirable.

The working hours defect (WHD) indicator shows the percentage of the employed population working weekly hours outside the range. Working too little, in relation to normal levels in that society, may prevent workers from participating in the productive organisation and so feel excluded, detached or unable to advance their careers. It can also give workers the perception that their contribution to society is of minor importance. Working too much is unhealthy and stressful as it can increase the likelihood of working disease or accidents that can interfere with the worker's familial and personal life.

The indicator on working hours is widely used in the study of decent work. Anker et al. (2002) place the indicator 'excessive (and extreme) hours of work' ${ }^{3}$ under four out of eleven aspects of decent work: adequate earnings, decent hours, combining work and family life, safe work environment. They also analyse insufficient working hours with the indicator 'time-related underemployment rate', which is part of three aspects of decent work: employment opportunities, adequate earnings and decent hours.

Bescond et al. (2003) also count the effective number of worked hours but, according to their proposal, a decent work deficit is identified only when this excess is not freely chosen for personal reasons. Such a distinction is not made in this proposal. If the amount of weekly hours worked is greater than the threshold it constitutes a working hours defect, even if it was chosen spontaneously. It is assumed that working too much or too little may be seen as a free choice but this may actually be driven by some form of constraint such as a confusion between self-identity and one's own profession, an exceptionally high conversion rate, ${ }^{5}$ or disregard or unease about one's own job or working place. An individual should neither work too much or too little to preserve the capability to be a 'fuller social person' (Sen, 1999: 15) or to reach an 'omnilateral development' (Marx, 1875: 12).

The second basic indicator is the physical safety defect (PSD). Another fundamental aspect of decent work is that workers should not be in physical danger in their working environments. This would compromise the capability to 'live long and have a good life' (Sen, 1999: 14). Accidents are another obstacle to the conversion of income (or other resources) into functionings. Assuming that no more than one accident or disease can be related to the same worker in any year, the PSD is obtained by summing up working accidents and working diseases and dividing that total by the number of employed people. The percentage of workers involved in accidents should be nil, so every percentage greater than zero is a physical safety defect. Ghai (2002: 17) examines 'working conditions' of decent work only through 'accidents and deaths at work in relation to the employed population'. The PSD is similar to the indicator proposed there, except that in the present proposal working diseases are added to accidents. In Anker et al. (2002: 50, 18) there is also the 'fatal injury rate' indicator among indicators of 'safe work environment'.

The third basic indicator is the legality of jobs defect (LJD). This shows the share of nonregular working hours as a percentage of the total amount of regular and non-regular working hours. For Sen (1999: 38) 'transparency guarantees' are instrumental freedoms that are able to advance the general capability $^{6}$ of people; these are better assured when a labour relationship is managed under formal rules. Working hours that escape formal rules therefore constitute a labour unfreedom. 
Anker et al. (2002: 16) introduce an 'informal economy employment' indicator under the category of 'economic and social context for decent work'. In this proposal the idea is that this indicator is among the basic aspects of decent work, because performing one's working activities in a nonregular way affects all the other components in unpredictable ways. The target of the LJD indicator is zero because in industrialised countries non-regular work should not exist. Many decent work approaches are criticised for being better applicable to industrial market economies and this is a valid critique for this indicator. While it may be possible that in non-industrialised countries good working conditions can also be found in non-market productive situations, it is of crucial importance to record non-regular work in industrialised countries as an unfreedom. This is because it is in the formal sector that the most righteous linkages between people are concentrated.

The fourth basic indicator is unemployment rate pressure (URP). This is meant to be a proxy of the worker's unfreedom to change jobs. Due to the importance of getting the status of worker to interact within society, a worker can decide to leave a job for personal reasons only if the economic environment - in terms of employment, unemployment and job creation - offers real alternatives. 'Having an $\mathrm{x}$ when there is no alternative may be sensibly distinguished from choosing $\mathrm{x}$ when substantial alternatives exist' (Sen, 1999: 76). Since leaving a job for a worker actually means trying to change jobs, or maybe changing from employee status to one of self-employed, the target value is, for simplicity's sake, no unemployment. This should indicate that workers are free to leave their jobs without being subordinated to the hazard of unemployment. This indicator is derived from adding discouraged people to workers unemployed for more than one year, and dividing this sum by the labour force augmented with discouraged people. ${ }^{7}$ The unemployment rate (or youth/female/wageemployment-specific unemployment rate) is taken into account in most of the proposals on decent work but usually as an indicator for employment opportunities (Ghai, 2002; Anker et al., 2002; Bescond et al., 2003) or for gender discrimination (Ghai, 2002).

\subsection{Complementary Level}

\subsubsection{Relations profile}

The relations profile regroups indicators linked to the social aspect of working. The remuneration of labour is influenced by but hardly identified with its marginal productivity. On the contrary, and according to the new Keynesian economic school (Lindbeck and Snower, 1986; Shapiro and Stiglitz, 1984; Azariadis, 1975; Baily, 1974; Gordon, 1974), wages are mostly influenced by social relations. The same job can be rewarded and perceived differently among different societies which is why information about earnings is introduced here in the section dedicated to relations. In other approaches wage information is managed in the sense of income-poverty analysis. The benefit of highlighting this kind of relation is that through wages workers can achieve many important functionings. But, as Sen (1999: 84) observes, 'since income remains only instrumentally important, we cannot know how significant the income gaps are without actually considering the consequences of the income gaps'.

Most constitutional democracies endorse the idea that every job should give sustenance to the worker, ${ }^{8}$ so this indicator is not intended to evaluate income-poverty or income-distribution. Rather it is intended on the one hand to measure the difference in remuneration levels between actual monetary entitlements and the perceived need for monetary credit, and on the other hand the difference between a selected threshold and average wages. Two indicators are proposed in this section: monetary sufficiency (MS) and monetary enrichment (ME).

Monetary sufficiency compares labourers' personal judgments on an earning level that permits them to live without difficulties with their effective average earning. The judgement of labourers on 
the monetary entitlements that they would reckon sufficient to live without difficulties is, when available, precious information because it can be interpreted as a revealed conversion rate. The indicator therefore helps to reveal the sufficiency, abundance or scarcity of monetary entitlements.

The second indicator proposed, monetary enrichment, is intended to enable comparisons between average wages. The average wage of a specific group of labourers is taken as a point of reference (a sort of threshold), and the distance between this and the other average wages in the economy is analysed. If this distance is narrowing it may mean that the other wages are lowering through the threshold, or that the threshold is rising. If the growth rate of this distance is falling it can mean that there is a general levelling towards the threshold.

The second relations indicator is educational enrichment (EE). The idea that every job should be meaningful is part of the frame of the Italian constitution, ${ }^{\prime}$ and it is noticeable, especially in a knowledge society, that a worker gets a personal reward for being continuously educated while working. 'Education ... improves the quality of life directly ... [it] also increases a person's ability to earn an income and be free of income-poverty as well' (Sen, 1999: 90). This is simultaneously a gain in productivity for the working organisation and a personal resource inseparable from the more valuable worker. The indicator is the share of the employed population which has attended a course in relation to their occupation in the last 12 months. The indicator here is identical to the 'employees with recent job training' which Anker et al. (2002: 21, 7) insert in the aspect called 'adequate earnings and productive work'. Here the highest percentage possible is desired, although a low one is not considered as an unfreedom.

The last indicator of this profile is freedom to voice (FV). Strikes are chosen as an indicator of the importance of the worker's voice. The same data was chosen by Anker et al. (2002: 7) as the indicator for 'social dialogue and workplace relations'. A useful proxy could be union density (as suggested by Ghai, 2002), but for some countries, including Italy, this information is harder to find at a territorial level. Unfortunately information about strikes is tricky because it can happen that a circumstance characterised by many strikes is more linked to difficult circumstances in the labour market rather than to moments of freedom. Moreover, 'it is possible to attach importance to having opportunities that are not taken up' (Sen, 1999: 76), such as the opportunity to call a strike without having reasons to actually do it.

\subsubsection{Fairness profile}

The third aspect - the fairness profile - collects indicators showing how personal characteristics not related to the professional profile influence job access. It also identifies if the working environment is significant. This profile is composed of two indicators, both deeply influenced by the peculiarities of the labour market and society under analysis. No topic is identified in absolute form, but the target is the absence of any observable discrimination and absurd working practices. As in the basic profile, this profile adopts the methodology of looking for the decent work deficit.

The first indicator within this aspect is called irrelevance of private characteristics defect (IPCD). Its aim is to detect parallels between the distribution of jobs and personal characteristics that are not related to the profession, such as sex, religious creed, ethnic or minority identity, and so on. In the Italian case, for example, sexual discrimination can be detected when looking at the share of women in top employee positions. The same indicator is proposed in decent work approaches under different labels. These include the 'distribution of skilled jobs' by sex (Ghai, 2002: 22) or 'occupational segregation by sex' or 'female share of employment in managerial and administrative occupations' (Anker et al., 2002: 43). 
The second indicator is called hanging work (HW) which records the incidence of extended non-productive working conditions. In the Italian case, for example, the practice of cassa integrazione $e^{10}$ does not interrupt the status of workers but for various economic reasons allows employers to push aside peripheral workers. This is meant to be temporary but can last for years while a specific contingent problem in the firm is being solved. This practice is socially important and specific to larger enterprises where the state partially stands in for the employer to pay wages in order to contain the risk of violent social insecurity. Apart from this, the significance of this practice for work is nil; the worker still gets the salary but does not remain with the production system. This indicator has been called hanging work to give the idea of suspension. 'A person who is denied the opportunity of employment' - in this case of working - 'but [being] given an handout from the State ... may look a lot less deprived in the space of incomes than in terms of the valuable opportunity to having a fulfilling occupation' (Sen, 1999: 94).

In the other decent work approaches this is recorded differently. Here hanging work is seen as negative because it compromises the meaning of work. But in others (Ghai, 2002; Anker et al., 2002) the sense is positive, because it is an additional component to public expenditure on social protection. Ghai (2002) asks if it is possible to prioritise decent work components, and agrees with Ritter (2005) that trade-offs and synergies between them can only be explained through access to complete micro data.

The proposed approach ranks hypotheses by two levels to collocate profiles. The fundamental level is the basic profile, which is intended as indispensable, while relations and fairness profiles come together in a subordinated level. This is because no social remuneration can compensate awful personal basic decent work defects, and in judging work practices the presence of wrong conditions (unfreedoms) is worse than the absence of right conditions (unreached functionings). This distribution in two levels confers the decision of what decent work is onto the subject identity of the worker - the intended beneficiary of decent work.

\section{3. $\quad$ 1996 -2012: The Italian Labour Market Changes}

During the last 15 years, the institutions of the Italian labour market have been reformed. Since 1996 four main reforms have changed its structure. The first concerned the deregulation of the employment agency system and the others have introduced more labour flexibility, ${ }^{11}$ in compliance with the 1997 European Employment Strategy and the 2000 Lisbon Strategy.

Flexibility is part of a wider European approach in which member states pursue a new social model known as flexicurity. This neologism was created in 1995 by Professor Hans Adriaansens and Ad Melkert, the Dutch Minister of Social Affairs (Wilthagen and Tros, 2004). It combines two opposing concepts: flexibility and security (Atkinson, 1984). Greater labour flexibility should be balanced by social security through income security with the goal of increasing employability to reduce unemployment and increase employment.

In the early 1990s Italy was affected by a dramatic economic crisis derived from currency and public finance problems that deeply affected the labour market (Valli, 1993: 297-300). Decreased employment activity rates led to greater unemployment and long-term unemployment, and labour productivity continued to decrease as it had before the crisis (Figure 2).

The deregulation of the employment agency system was the first Italian labour market reform designed to improve these labour market indicators. A total re-organisation of the employment system was realised to mediate labour demand and labour supply in order to reduce unemployment, including frictional and structural unemployment. But on the basis of empirical evidence, these measures were inadequate to address unemployment. Competition between private labour agencies 
(LAs) and public employment services (PES) in formal job search channels produced poor results. In 2010 only 3,4\% of workers had found their jobs through the PES (most of them relate to compulsory employment) and 2,4\% through labour agencies. Over 20 years the mediation power of this system is only 5,8\% (Mandrone and Radicchia, 2011), which is insignificant in comparison with informal recruitment channels (referrals by family and friends) that mediate about $30 \%$ of workers.

\section{$\underline{\text { Figure } 2}$}
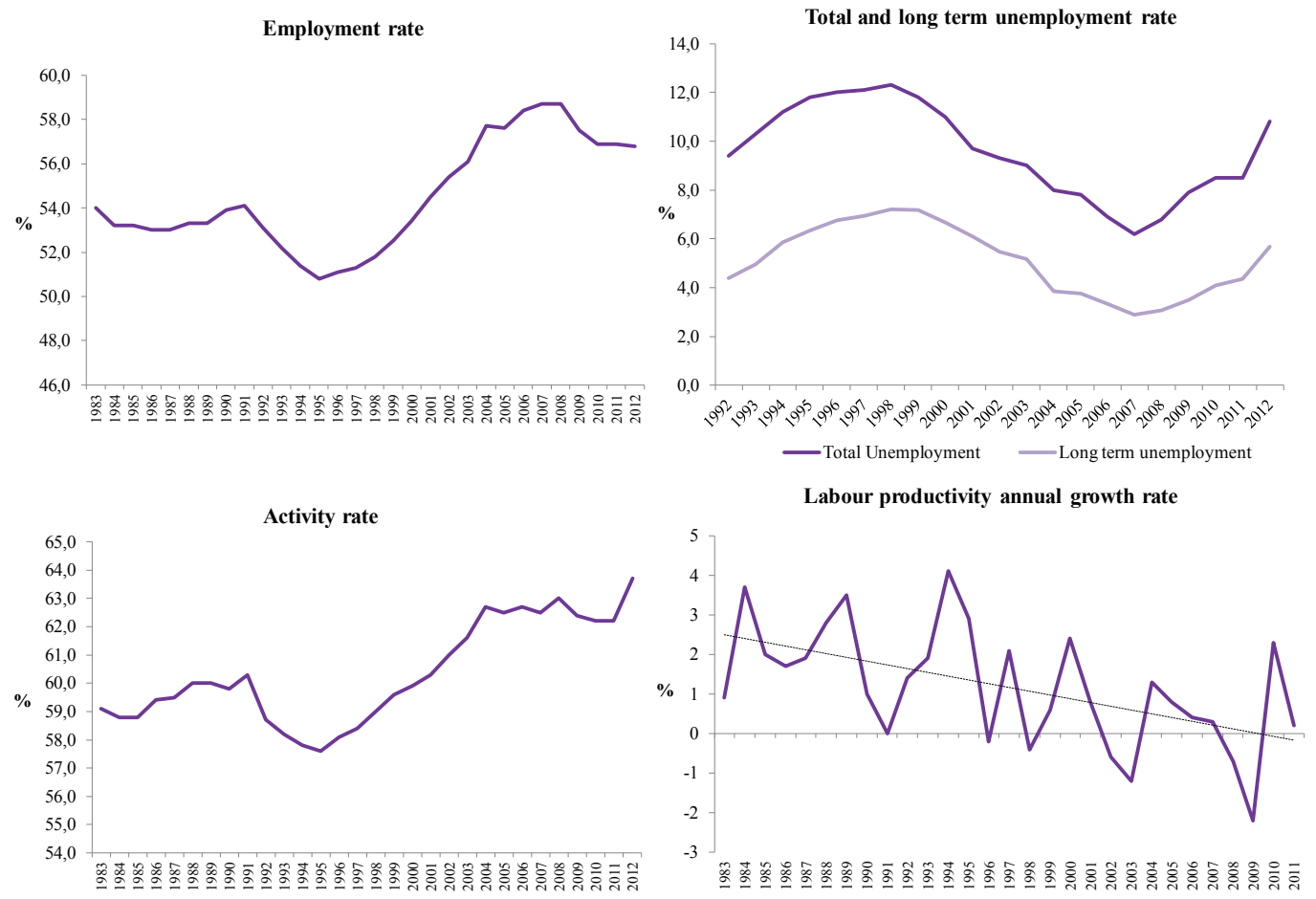

Source: Own elaboration on Eurostat and OECD data

Yet Italy continues to allocate a decreasing share of GDP to active labour market policies just 0,31\% of GDP in 2011 (Figure 3) compared to an EU15 average of 0,56\% of GDP. In 2011 Italy dedicated only $0,03 \%$ of GDP to labour market services (PES) compared to Germany's 0,55\% and the EU15's 0,25 \% (in 2009). Only 0,14\% of Italian GDP is devoted to training, while the figure in Germany is $0,26 \%$ and in Denmark $0,50 \%$.

New temporary labour contracts were introduced (Treu and Biagi laws) to reduce rigidity and increase flexibility in the Italian labour market. Among them, the more widespread 'atypical contracts' were Collaborazione coordinata e continuativa (the so-called Co.co.co.) and the later Collaborazione coordinata a progetto (the Co.co.pro.) that were cheaper and more flexible (in the sense of an easier way of hiring) in relation to temporary contracts and considering workers as independent. 


\section{Figure 3}

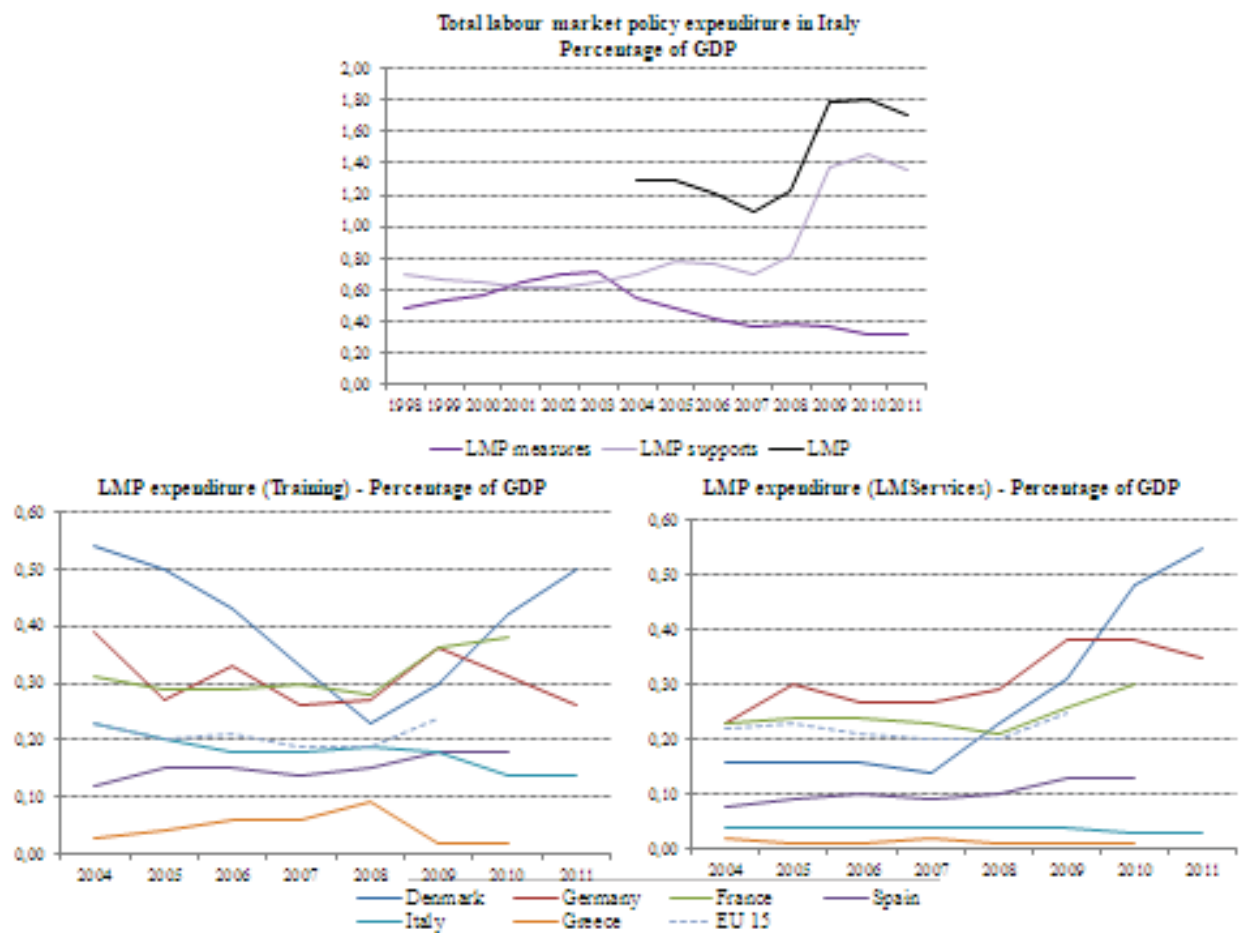

Source: Own elaboration on Eurostat data

These kind of jobs, in fact, were project-related, coming to an end when the project was finalised, and workers were not subject to the commitment and protection (social security) provided by a dependent job - i.e. working time, sick pay or unemployment benefits.

These new jobs were designed to help employers match the labour force to the firm's productive process, and made atypical contracts very attractive for employers with the risk that they have been overused. There has been a progressive increase in temporary jobs, and among them the atypical ones (Figure 4), and a decrease in permanent ones. In the period in which those reforms have been enforced (1997 to 2003), the data shows a sensible increase, in particular in 2004 where the category of temporary workers showed an increase of 2,4 percentage points.

But in 2009, when Italian real GDP growth rate registered $-5,5 \%$ (Eurostat data), the positive trend of temporary workers suffered a slowdown, although with growth later. In the same year the employment rate presented a decreasing trend, and from 2011 the rate levelled off at nearly 57\%. Temporary workers have been the first to be affected by the crisis. Their numbers have increased from 2010 when the employment rate decreased or levelled off, indicating a shift from permanent to temporary employment.

This qualitative change of employment would not be troubling if Italy implemented an employability approach. But this is not the case because the employment agency system does not work appropriately and the unemployment benefit system is inadequate. These reforms increased precariousness by introducing flexibility, and changing the employment structure, while measures on security were less incisive (Tridico, 2009). The universal scheme for unemployment benefits that has 
been built in Italy is not systematic enough. It is an allowance which is only accrued for a minimum number of working days if unemployed workers comply with the benefit requirements. In particular, only permanent and temporary dependent workers were entitled to unemployment benefits according to the requirement above. But atypical workers were not protected until 2009, when the so-called unemployment benefits for Mobilità in deroga (redundant workers) were introduced without preventing precariousness. Furthermore, with the exception of the latter, these benefits are not linked to training programmes that facilitate re-insertion into the labour market.

\section{Figure 4}
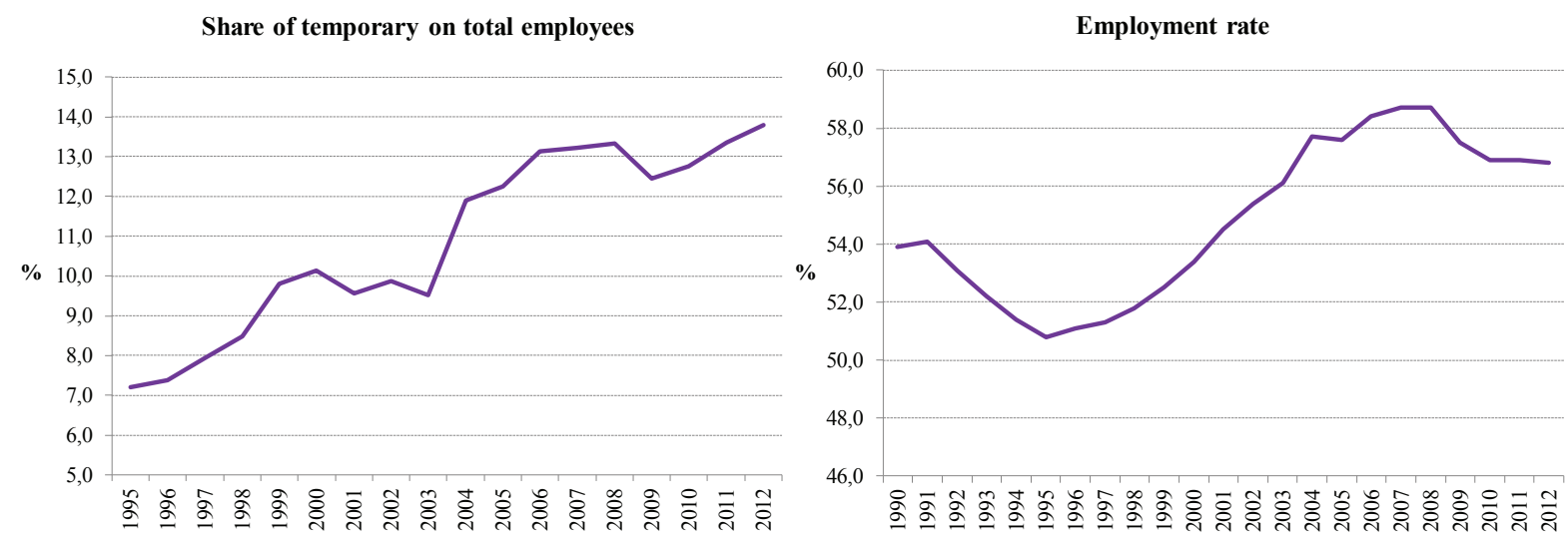

Source: Own elaboration on Eurostat data (workers 15-64 years old)

It is in this context, and that of the global economic crisis, ${ }^{12}$ that the Fornero reform of 2012 was composed. It aimed to downsize flexibility and precariousness, by opposing the abuse of atypical jobs and reorganising the unemployment benefit system. Nevertheless, this new unemployment benefit - Assicurazione Sociale per l'Impiego (AspI), Employment Social Security in English - always required job experience of two years at least, as did the previous one. Before the fall in unemployment status, atypical workers were not covered by this social security. Therefore, because the reforms did not present a universal definition of the status of unemployed, a fragmented system developed with inadequate income security and growing disparity between workers and the unemployed.

Finally, these labour market policies were not part of a wider strategic programme for development and growth policies (Fadda, 2005) and so did not resolve the labour market's problems.

\section{Evaluating Decent Work in Italy}

This description of the decent work in Italy starts from 2000 and has been realised using data from different sources, as described above. To evaluate decent work in Italy we analyse the four elements of the basic profile: working hours defect (WHD), physical safety defect (PSD), legality of jobs defect (LJD) and unemployment rate pressure (URP) that will be calculated as follows. 
The right weekly number of working hours for Italy is reckoned to be between 20 and 40 per week, chosen because they correspond to a part-time and a full-time employment contract respectively. The WHD is calculated at a national level for 2004 to 2011 for people working more than 40 hours and people who work between 1 and 10 hours. We then divide them all by the total employed. For 2000 to 2003 those working more than 40 hours are added to those working 1 to 15 hours.

The second basic indicator concerns safety at work. The PSD is calculated using data from INAIL, summing up accidents and diseases in the year and dividing them all by the number employed.

\section{Figure 5}

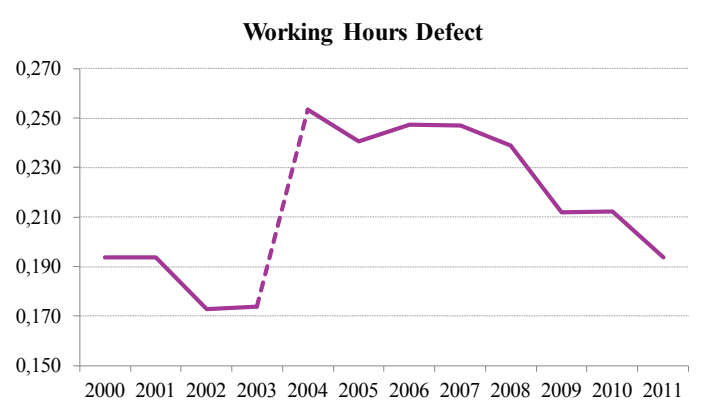

Source: Own elaboration on Istat data

Lagality of Jobs Defect

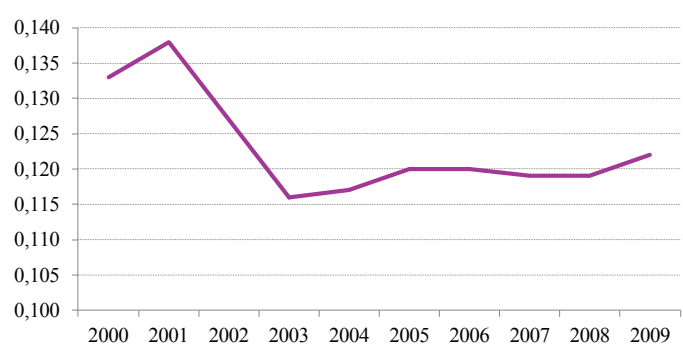

Source: Istat

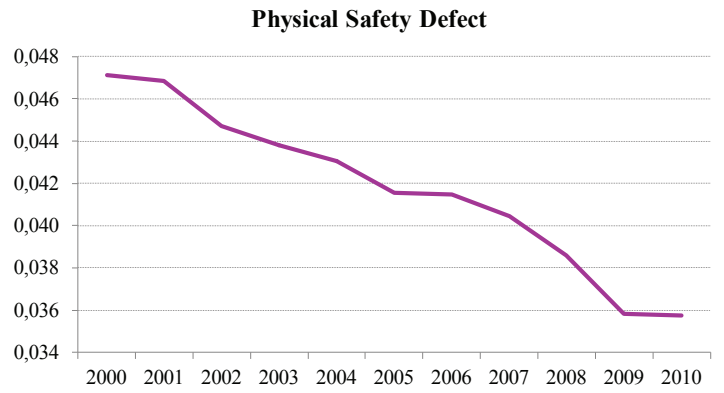

Source: Own elaboration on Inail data

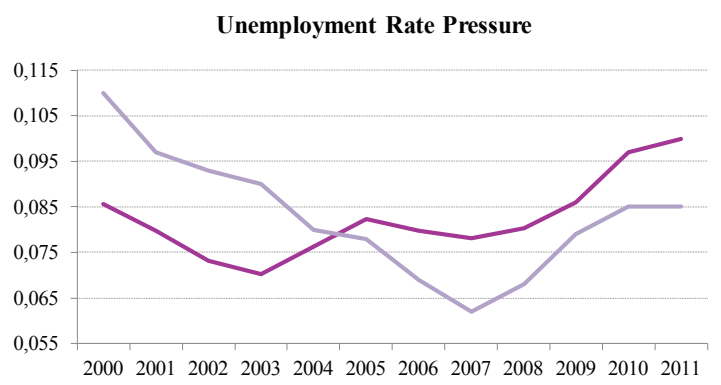

Source: Own elaboration on Eurostat data $\quad$ URP $-U R$

The ISTAT percentage of irregular working hours on the total number of regular and irregular working hours is given as LJD. For the last indicator, we chose to calculate an unemployment rate which included workers unemployed for more than 12 months combined with the 'discouraged' population. The two groups were added and this sum was divided into the combined value of the labour force and the discouraged.

Figure 5 shows that two elements of the decent work basic profile are ameliorating with time (WHD and PSD), while the other two are worsening (LJD and URP). The first graphic shows a data break between 2003 and 2004, corresponding to a change in the survey methodology but a descending trend in the working hours defect is in both groups of data. In 2004 one-fourth of workers were spending an incorrect amount of time per week at work (25,3\%). In recent years, 2009 and 2010, the WHD concerns a little more than one-fifth of workers. The physical safety defect trend is falling constantly. In 2000 less than $5 \%$ of workers were involved in accidents or had illness from job activities; the trend continued to decline for eleven years by about one percentage point. It 
is useful to read this data jointly with the indicator regarding non-regular work because areas characterised by high levels of irregular work do not reveal high levels of working accidents and diseases. From 2001 to 2003 there is a rapid decrease in the percentage of legality of jobs defect, corresponding to the enacting of laws ${ }^{13}$ that regulate the employment of familial collaborators. After that moment a softer but continuous growth is on-going through years 2003 to 2009. Although we cannot confirm a cause between people having these two kinds of working defects, we can conjecture that the LJD can prevent the data on accidents from being plausible.

From 2007 the unemployment rate pressure shows an increasing trend and is higher than the commonly used unemployment rate in most of the period considered. In 2004 the URP has lower values than the unemployment rate. This could mean that unemployment of less than one year is more incisive than long-term unemployment for general unemployment. After that year the unemployment rate drops two points to 2007 where the URP falls by a half point, implying that the part of the population in URP is less reactive to market opportunity changes. When the unemployment rate stops growing, from 2010 to 2011, the URP continues. This can be a sign of a shift of people from short-term unemployment to long-term unemployment. In this approach it seemed more interesting to choose this corrected rate because the aim here is to use it as a proxy for the unfreedom of workers to leave their jobs and try to get others. If the pressure of long-term unemployment and discouragement is high on society, every worker would take this into account while evaluating the choice to continue performing the jobs they already have.

From 2008 to 2009 the decent work basic profile seems to reflect movements related to the economic crisis. The first indicator, WHD, is constantly improving but it is possible that a more reasonable number of working hours is a side-effect of minor employment in terms of working hours more than a change in the organisation of labour.

The PSD presents a slowdown of the trend and this should be a good sign, but in the same period there is an increase of the LJD. An increase of the LJD could be connected to tax avoidance that can be stronger in a period of economic uncertainty, and this could lead to a more unrealistic perception of the dimension of working accidents and deaths. The URP could be considered the most reliable indicator because, as it is proposed here, it shows the 'climate' that the workers face. This indicator been growing uninterruptedly since 2007, at a time of long-term unemployment when workers would be less free to get into conflicts with employers because of the fear of becoming unemployed.

In conclusion, and acknowledging the limits of interpreting the data, the empirical evidences implies that two out of four basic profile variables are moving towards a decent work situation. The labour market institutional change probably affected decent work variables, especially in the period of the most severe crisis. Some evidence of these years of crises shows how the major impact on employment affected industrialised countries characterised by flexible labour market (Tridico, 2013). From 2008 the two defects that were decreasing (WHD and PSD) show a moment of stability, while the others (LJD and URP) get even worse.

\section{Conclusions}

The aim of this paper was to introduce our interpretation of the ILO's concept of decent work and to define the variables that characterise it in a developed country like Italy. The approach has been tested by analysing the case of Italy and observing the impact on decent work of labour market laws and reforms of the last 15 years. We articulated decent work through three profiles: basic, relations and fairness. These were prioritised into two levels: the basic level as the fundamental one, and relations and fairness as complementary, regrouping indicators linked to the social aspect of 
working. This framework is here implemented in a developed country, but it is valid also for all other kinds of society.

The basic profile organised essential indicators, characterised as the ones more intimately linked to daily working conditions. For these indicators it was possible to point out a chosen desired value, and the gap, whether positive or negative, between the actual and the desired value was recorded as a decent work basic defect. This basic fundamental level was composed by four variables: a working hours defect (WHD) indicator which showed the percentage of the employed population working a number of weekly hours as different from those within the working hours range; a physical safety defect (PSD) obtained by summing up working accidents and working diseases and dividing by the number of employed people; a legality of jobs defect (LJD) that shows the share of non-regular working hours on the total amount of regular and non-regular working hours; an unemployment rate pressure (URP) as a proxy of the unfreedom to change jobs.

From the 1990s, the Italian labour market has been affected by several reforms that deregulated the labour market to reduce unemployment and increase employment. In 1996 competition between private labour agencies and the public employment service was introduced, and later new temporary labour contracts like Co.co.co. and Co.co.pro. increased labour flexibility. These were cheaper and more flexible than temporary contracts. The abuse of these atypical contracts is evident in the shift from permanent to temporary employment. This qualitative change of employment combined with an inadequate unemployment benefit system increased precariousness.

The empirical analysis on decent work in Italy used time series data from 2000 to 2011 from different sources. These included the ISTAT labour force survey, statistics on accidents and diseases from INAIL, data from the INPS observatories on workers and the Eurostat database. Observing data from this period, the four indicators composing the basic level have different trends. WHD and PSD show a gradual decrease that could be interpreted as an approach to the decent work condition, while the other two indicators (LJD and URP) show an opposite trend of worsening of the defects and estrangement from the desired situation.

The labour market institutional change that occurred therefore probably affected decent work variables but in different ways. Focusing in particular on years characterised by the economic crisis, from 2008 the two defects that were decreasing show a moment towards stability, while the others get worse.

Various interpretations could explain the evidence of decent work indicators. In the perspective of decent work analysis, a progressive decrease of WHD and PSD indicators sounds like a positive result. But it is possible to recognise other interpretations. In the context of an economic crisis a decrease of working hours could be unassociated with an improvement of human resources management or productive process, but could be related to a reduction of production levels caused by a decreasing market demand. Similar interpretation could be made in respect of PSD indicators. Furthermore, a decrease of accidents associated with increases of undeclared work (included into the LJD indicator) could represent a symptom of deeper problems. Italy is a country where the shadow economy is widespread, and organised crime and corruption affect the legal economy. According to this and in the presence of an economic crisis that exacerbated Italian structural economic problems, the probability of falling into the black economy increases. Accidents that happen on undeclared work probably increase too, but are not reported in the official statistics. In this sense a decreasing PSD indicator could represent more serious problems, referring to a wider scenario.

Last but not least, URP indicators strengthen the current interpretations. An increase of longterm unemployment and discouraged people describes more than what happens in the labour 
market. Those variables are strictly linked to the previous indicators, while describing a society exhausted and disenchanted.

In conclusion, biased decent work analyses are possible if realised out of context. In this sense, they shed light on the aspects described above, and are fundamental for an authentic interpretation of decent work analysis.

\section{NOTES}

1. The capability approach, by Amartya Sen, is a way to intend development as the 'process of expanding real freedoms that people enjoy' (Sen, 1999: 3), so as to allow 'people to lead the kind of lives they have reason to value' (Sen, 1999: 10).

2. We live in a world of unprecedented opulence ... and yet we also live in a world with remarkable deprivation ... individual agency is, ultimately, central to addressing these deprivations ... we have to see individual freedom as a social commitment' (Sen, 1999: xi, xii).

3. Excessive hours of work are more than 48 per week, according to the ILO Convention N.1/1919; extreme hours of work are more than 60 per week.

4. 'Percent of employed population working less than hours threshold, but available to work and wanting to work additional hours' (Anker et al., 2002: 29).

5. In Sen's (1999) theory the 'conversion' is the relation through which every human being can transform income into functioning, it is 'neither constant nor in any sense automatic and irresistible' (Sen, 1999: 109). It is strongly influenced by environmental contingencies and personal conditions.

6. 'A person's capability refers to the alternative combinations of functionings that are feasible for her to achieve ... the substantive freedom to achieve alternative functionings combinations ... the freedom to achieve various lifestyles' (Sen, 1999: 75). Synthetically, a 'capability set' is the whole of the real opportunities that a person has.

7. Discouraged people are those who do not search for work because they consider their chances of finding a job too low.

8. For example, in the Italian Constitution, art. 36, paragraph 1, it is stated that a 'worker has the right to a remuneration proportionate to the quantity and quality of his/her work and in any case sufficient to ensure him/herself and his/her family a free and decent existence'.

9. In the Italian Constitution, art. 35, paragraph 2 states that '(the State) looks after education and professional elevation of workers'.

10. Cassa integrazione is a special kind of Italian unemployment insurance. When firms are in trouble, they can use this institution which does not interrupt the status of workers although the employer may put the workers aside temporarily. In these circumstances, workers in cassa integrazione work part-time in the firm or do not work at all while the problem is being solved. So workers in cassa integrazione are not fired, and received about $80 \%$ of their wages, although this percentage decreases as time goes on. The time limit of cassa integrazione is four years.

11. L. 608/1996, D.lgs 469/1997, Bassanini Law (L. 59/1997), Treu Law (L. 196/1997), Biagi Law (L. 30/2033), Fornero reform (L. 92/2012). In 2003 competition between private labour agencies (LA) and the public employment service (PES) was also introduced. The Fornero 
reform purposes present a countertrend in respect to the previous reforms, increasing social security efficiency and reducing labour flexibility.

12. The last economic crisis has seriously compromised social-economic variables and labour market variables, and resulted in an increase in the unemployment rate (according to Eurostat data, it was 12\% in March 2013), and in particular the youth unemployment rate (over 35\% of the 15-24 age group in 2012). There has been a progressive increase of NEETs (young people 18-24 not in employment, education or training) from $20 \%$ in 2003 to $27 \%$ in 2012 . There has also been a sharply decreasing trend of real labour productivity per employed. If $2005=100$, labour productivity in 2013 was 95,1.

13. L.189/2002 and L.222/2002.

\section{REFERENCES}

Anker, R., Chernyshev, P.E., Mehran, F. and Ritter, J. (2002) 'Measuring decent work with statistical indicators', ILO Working Paper No.2. Geneva: ILO.

Assemblea costituente della Repubblica Italiana (1947) 'Costituzione della Repubblica Italiana’, G.U. No. 298/1947.

Atkinson, J. (1984) Flexibility, uncertainty and manpower management, IMS Report No.89. Brighton: Institute of Manpower Studies.

Azariadis, C. (1975) 'Implicit contracts and underemployment equilibria', Journal of Political Economy, 83(6): 1183-1202.

Baily, M. (1974) 'Wages and employment under uncertain demand', Review of Economic Studies, 41(1): $37-50$.

Bescond, D., Chataignier, A. and Mehran, F. (2003) 'Seven indicators to measure decent work: An international comparison', International Labour Review, 142(2): 179-212.

EUROSTAT 2000-2011. Labour market statistics database. Available online at http://epp.eurostat.ec.europa.eu/portal/page/portal/statistics/themes (Accessed between January and July 2012).

Fadda, S. (2005) 'Per un'integrazione tra politiche del lavoro e politiche di sviluppo', Argomenti 14: 527.

Ghai, D. (2002) Decent work: concepts, models and indicators, ILO Discussion Paper No. 139. Geneva: ILO.

Godfrey, M. (2003) Employment dimensions of decent work: Trade-offs and complementarities, ILO Discussion Paper No. 148. Geneva: ILO.

Gordon, D.F. (1974) 'A neoclassical theory of Keynesian unemployment', Economic Inquiry, 12(4): $431-459$.

International Labour Organisation (ILO) (1919) 'Convention No. 1 - Convention limiting the hours of work in industrial undertakings to eight in the day and forty-eight in the week', $1^{\text {st }}$ session of the International Labour Conference. Washington: ILO. 
International Labour Organisation (ILO) (1999) Report of the Director-General: Decent Work, $87^{\text {th }}$ Session of the International Labour Conference. Geneva: ILO.

International Labour Organisation (ILO) (2013) 'Meeting on measuring and monitoring decent work lessons learnt from MAP countries: Meeting report'. Geneva, ILO.

Krauser, A. (2011) Work to live or live to work? Unemployment, happiness, and culture, IZA Working Paper No.6101. Bonn: Institut zur Zukunft der Arbeiter.

Law 20 November 1996, No. 608 about the subject 'Conversione in legge, con modificazioni, del decreto-legge 1 ottobre 1996, n. 510, recante disposizioni urgenti in materia di lavori socialmente utili, di interventi a sostegno del reddito e nel settore previdenziale’. G.U. 30 November 1996, No. 281.

Law 15 March 1997, No. 59 about the subject 'Delega al Governo per il conferimento di funzioni e compiti alle regioni ed enti locali, per la riforma della Pubblica Amministrazione e per la semplificazione amministrativa'. G.U. 17 March 1997, No. 63.

Law 24 June 1997, No.196 about the subject 'Norme in materia di promozione dell'occupazione'. G.U. 4 July 1997, No. 154.

D.lgs. 23 December 1997, No. 469 about the subject 'Conferimento alle regioni e agli enti locali di funzioni e compiti in materia di mercato del lavoro, a norma dell'articolo 1 della legge 15 marzo 1997, n. 59'. G.U. January 1998, No. 5.

Law 30 July 2002, No. 189 about the subject 'Modifica alla normativa in materia di immigrazione e di asilo'. G. U. 26 August 2002, No. 199.

Law 9 October 2002, No. 222 about the subject 'Conversione in legge, con modificazioni, del decreto-legge 9 settembre 2002, $n$. 195, recante disposizioni urgenti in materia di legalizaazione del lavoro irregolare di extracomunitari’. G. U. 12 October 2002, No. 240.

Law 14 February 2003, No. 30 about the subject 'Delega al Governo in materia di occupazione e mercato del lavoro'. G. U. 26 February 2003, No. 47.

Law 28 June 2012, No. 92 about the subject 'Disposizioni in materia di riforma del mercato del lavoro in una prospettiva di crescita’. G.U. 3 July 2012, No. 153.

Lindbeck, A. and Snower, D. (1986) 'Wage setting, unemployment and insider-outsider relation', American Economic Review, 76(2): 235-239.

Mandrone, E. and Radicchia D. (2011) La ricerca di lavoro: $i$ canali di intermediazione e i Centri per l'impiego, Collana studi ISFOL, 2/2011. Rome: ISFOL.

Marx, K. (1976[1875]) Critica al programma di Gotha, Editori Riuniti. Rome: Editori Riuniti.

National Institute for Assurance on Accidents at Work (INAIL) (2000-2010) Statistical data bank archives. Available online at bancadati.inail.it/prevenzionale (Accessed between January and July 2012).

National Institute of Statistics (ISTAT) (2000-2011a). Labour force survey. Available online at dati.istat.it (Accessed between January and July 2012).

National Institute of Statistics (ISTAT) (2000-2011b) Monthly survey on employment, working time, earnings and labour cost in large enterprises. Available online at dati.istat.it (Accessed between January and July 2012). 
Ritter, J.A. (2005) Patterns of job quality attributes in the European Union, ILO Working Paper No. 51. Geneva: ILO.

Saith, A. (2004) Social protection, decent work and development, ILO Discussion Paper No.152. Geneva: ILO.

Sen, A. (1999) Development as freedom. Oxford: Oxford University Press.

Shapiro, C. and Stiglitz, J. (1984) 'Equilibrium unemployment as a worker discipline device', American Economic Review, 74(3): 433-444.

Stiglitz, J., Sen, A. and Fitoussi, J.P. (2009) Report by the Commission on the Measurement of Economic Performance and Social Progress. Available online at http://www.stiglitz-senfitoussi.fr/en/documents.htm (Accessed 7 March 2012).

Tridico, P. (2009) Flessibilità, sicurezza e ammortizzatori sociali in Italia, Departmental Working Papers of Economics No. 107. Rome: University Roma Tre.

Tridico, P. (2013) 'The impact of the economic crisis on EU labour markets: A comparative perspective', International Labour Review, 152(2): 175-190.

Valli, V. (1993) Politica economica macroeconomia e politiche di breve periodo. Il caso italiano. Roma: NIS.

Wilthagen, T. and Tros, F. (2004) 'The concept of "flexicurity": A new approach to regulating employment and labour markets', European Review of Labour and Research, 10(2): 166-186.

\section{BIOGRAPHICAL NOTES}

MARTINA LAVAGNINI has done socio-economic research on labour market and 'decent work' for the University of Roma Tre, the University Centre for the Study of Rome (CROMA) and the Regional Council for Economy and Labour of Lazio (CREL) on several occasions from 2009 to 2013. She has been part of the research team working for the PRIN 'Capabitaly: Measuring Human Development and Capabilities in Italy' under the coordination of Professor Pasquale De Muro. She later on worked as a marketing officer in several fields (medical, jewellery tele-selling), and she is now working in the ecotourism, notably cyclotourism, in the Rome area. [Email: martinalavagnini@hotmail.com]

ANTONELLA MENNELLA held a scholarship in Economics at the Department of Economics, University of Roma Tre. Her PhD was in Economic Science at the University of Rome 'La Sapienza'. She held a post-doctorate fellowship in Economics at the University of Roma Tre. She now has a scholarship in Economics at the Department of Economics, University of Roma Tre. Research interests: Labour economics, organised crime. [Email: antonella.mennella@,uniroma3.it]. 